\title{
Columbia and Her Sisters: Personifying the Civil War
}

\author{
Allison M. Johnson
}

A month after the bombardment of Fort Sumter and the beginning of hostilities between the Union and the newly formed Confederacy, Columbia, the female personification of the United States, slumbers peacefully amid the tumult. S.J.A.'s poem "Not Dead" (1861), printed in Harper's Weekly, the leading periodical of the day, begins with an epigraph taken from a "motto on a New York banner" - a flag most likely designed and produced by local women for a regiment: "The Union is not dead but sleeping." Through the "dark night of wickedness" caused by the rebellion, the people of the North must guard both "our Union and our liberty." S.J.A. calls on "each soldier's arm to grasp the sabre," since only the return of "each star by traitor bands disgraced"- - each seceded state - will allow the Union to "joyously" awake from her slumber and "never sleep again." The personified Union's slumber and intact state promise hope for future reconciliation and reunion but also warn of her vulnerability and need for protection. These characteristics make S.J.A.'s womanly Union representative of a wartime trope ubiquitous in print and visual culture on both sides of the conflict. Analogous female personifications of the Confederacy and, more often, individual states appear in Southern periodicals and illustrations; despite their similarities to Northern counterparts, they serve categorically opposed rhetorical purposes. While Columbia, traditionally interchangeable with the goddess of liberty, represents the Northern states and the hope of reunifica- 
tion, a group of Southern sisters imagines a new nation separate from the body politic of the Union.

Though Uncle Sam would replace Columbia as the most popular American personification by the beginning of the twentieth century, Columbia reigned supreme in the antebellum United States and during the Civil War era. Patriotic poems, cartoons, and illustrations calling for renewed determination and dedication to the cause of defeating the Confederacy habitually invoke the embattled and all-encompassing Columbia. Columbia's Confederate sisters, personifications of a fledgling nation and its constituent states and cities, wage a rhetorical war for legitimacy and for the ability to represent embattled femininity. Symbolic women call their nations to a war that only men may fight; however, they also face the threats of invasion and violence. Consequently, sexuality and nationalism are closely intertwined: to defend the nation-state is to shelter female bodies from rapacious enemies and to retain the purity and structural integrity of national borders and codes of law.

Closely tied to the rhetorical work of symbolic femininity is the actual war work of American women. As Drew Gilpin Faust notes, the Civil War necessitated the involvement of women and inspired a "discussion of women's appropriate relationship to war-and thus to society in general."2 Women on both sides of the conflict served as nurses, fought as soldiers, operated as spies, raised money and collected supplies for hometown regiments, and knitted socks for soldiers. ${ }^{3}$ Popular literature of the time reflects this involvement and service; alongside poems and articles detailing the heroic valor of soldiers, verses commemorating the service and suffering of nurses at the front and mothers, sisters, and lovers at home assert the significant contributions of actual women to the war effort. ${ }^{4}$ The bodies of women in Civil War literary and visual culture, encroaching on the territory of men, touched by the violence of conflict, and physically involved in the work of war, are very often revolutionary.

Whether removed from the battlefront or in the thick of the action, female forms assert the presence of real women's bodies in the process and progress of war. They also inhabit similar roles and express similar emotions to those inhabited and performed by Northern and Southern female personifications. This overlap allows for a reconfiguration of the public and the domestic as clearly delineated spheres. As the war invades the home front, the symbolic feminine inserts the lives, bodies, and experiences of real American women into public discourse and the literary and visual record of the conflict. Like American women, Columbia and her Confederate counterparts are mothers and sisters, roles that indicate the prevalence of the family metaphor in nineteenth-century American conceptions of the nation and its constituent parts. Significantly, both halves of the divided nation deploy the symbolic maternal feminine to define the stakes of the conflict and indicate the necessity of violence. Though female allegories often serve to remove or distance actual women from participation in the public and political realms, the bodies of Columbia and her sisters, threatened and torn by the war, disrupt this distancing by moving the symbolic 
feminine body into the physical realm of the war and more closely aligning the symbolic feminine with the physical bodies of American women.

\section{Bodies Politic}

Inherently allegorical, female personifications of nations have the potential to relegate women's political and social significance to the symbolic realm. Barbara Johnson indicates the tendency of allegory to perpetuate separate spheres of female and male action and influence, especially since "public art" tends to abstract the female form. ${ }^{5}$ The allegorical feminine appears as one of the justifications for violence: men must fight to protect their wives, mothers, daughters, and sisters. Personifications of the Union or the Confederacy serve as the focal point of calls to arms and rallying cries, but it is men and not women who are called and rallied. Allegory, as Paul de Man would remind us, creates distance while symbolism presents the possibility of "identity or identification." ${ }^{\prime 6}$ When female bodies allegorically represent the nation, women can remain removed from the actual process of nation building and nation protecting. According to Johnson, allegory allows for interpretation "through a predicate of embodiment, location, interest, and readability" (73). Embodied and readable, the female form provides a main casus belli for both sides of the war. However, Columbia and her sisters often act as both symbol and allegory, allowing for identification with actual American women and with more abstracted ideals of Union and freedom.

Historians, literary critics, and art historians have studied female personifications of countries and of the United States in particular, underscoring the interconnectedness of gender and nationhood, but there is no extensive study of Columbia and her sisters in literature and illustrations published during the war. Scholars also disagree on the prevalence and purpose of figures like Columbia. Mary P. Ryan and Elizabeth Young both recognize the silencing power of allegory and metaphor, Ryan describing the "benign but decorative" role of Lady Liberty in antebellum America and Young indicating the centrality of "voiceless" feminine representations to Civil War conceptions of the body politic." Discussing antebellum political culture, Anne Norton emphasizes the masculinization of the North and feminization of the South and indicates a "metaphoric disparity" between representations of a female Confederacy and a male Union in two collections of Civil War poetry. ${ }^{8}$ However, as this essay makes clear, poets and artists both North and South imagined and depicted their states and nations as female and often motherly.

As matriarchs or supportive sisters, female personifications indicate the centrality of the familial metaphor to American conceptions of nationhood. Antebellum Americans relied on familial relationships to understand their social and civic roles as citizens in a democratic nation. A number of scholars have examined the family as a central component in the formation of a uniquely American nationality and social order. In her study of artistic and novelistic 
depictions of familial violence, Shirley Samuels traces the interconnectedness of family, sex, politics, and race in the formation of American identity. ${ }^{9} \mathrm{C}$. Dallett Hemphill measures the growing significance of sibling relationships in the decades leading up to the Civil War in the "increasing use of this relationship as a metaphor for other relations," including church membership, friendship, and political activism. ${ }^{10}$ Portraying the "divided family" as a historical occurrence and a controlling metaphor during the Civil War, Amy Murrell Taylor argues that Americans attempted to understand the conflict through the "vocabulary of family," a vocabulary central to the continuing formation of national identity. ${ }^{11}$ Similarly, Drew Gilpin Faust notes that Southerners self-consciously endeavored to create a national identity, identifying themselves with the founding fathers and European nationalist movements as well as employing "metaphors of family and of organic duty."'12

As mothers and sisters, Columbia and her Southern counterparts participate in the constructs Hemphill, Taylor, and Faust describe and as such deserve recognition as central components of antebellum and Civil War conceptions of American identity and the national family; they are also significant milestones in what Patricia Vettel-Becker describes as the "search for a national identity, a continually contested process that originated with the founding of the republic itself." 13 As the mother of the nation, Columbia is defined primarily by her relationship to her children - the people of the United States. She mourns her fallen sons, a New World stabat mater dolorosa.${ }^{14}$ However, Columbia does more than mourn - she demands action, advocates for soldiers, leads the battle charge, lets slip the dogs of war, and enters the public realm of politics. Her relationship to the nation centers in her maternity but her action is not limited to that relationship.

An overview of Columbia's origins and development demonstrates her adaptability and the interconnectedness of race and gender in the formation of an American national identity. As Europeans began to explore the New World, artists imagined a welcoming indigenous woman, often nude and bedecked with feathers. This female and demonstrably native America appears in allegorical representations of the continents, an art form that became popular in the sixteenth century and remained so into the nineteenth. ${ }^{15}$ While the conquest and colonization of the Americas silenced millions of actual indigenous women, figurative and iconic native women continued to represent North America in European (and a few American) political cartoons and artistic renderings of the continent. ${ }^{16}$ With the advent of revolution, the figure E. McClung Fleming labels "Indian Princess" became the rebellious daughter of Great Britain, and, as Shirley Samuels argues, female bodies served to subsume "racial and sexual violence." 17

After the Revolution, female figures produced by American artists representing the new nation wore star-spangled robes instead of deerskin and their limbs were lily-white rather than tawny. As Americans continued to create a national identity, the iconic native woman was increasingly supplanted by the white Lady Liberty or Columbia. ${ }^{18}$ Though Joshua Taylor, in his study of artis- 
tic representations of America, argues Columbia did not belong to "geography or a particular race, but to the family of personified virtues," the figure's transition from dark skin to white skin underscores the exclusion of the racial other and the primacy of whiteness in the formation of a national symbol. ${ }^{19}$ Drawing on iconographic depictions of the goddess of Liberty, artists and writers combined togas, Phrygian caps, and eagle feathers to produce a new Caucasian personification of the nation..$^{20}$

Despite scholarly claims to the contrary, the Greek goddess-like Columbia was not replaced by two male personifications of the nation, Uncle Sam and Brother Jonathan, in the nineteenth century. ${ }^{21}$ Both male figures do appear in Civil War era political cartoons, a medium made possible by improvements in printing techniques, but they in no way supplant or surpass Columbia. ${ }^{22} \mathrm{~A}$ survey of the popular press during the Civil War confirms Columbia's primacy and popularity. ${ }^{23}$ Kristen Smith, in her collection of Civil War cartoons, argues that Columbia "symbolized the American people until the appearance of Brother Jonathan who became Uncle Sam." ${ }^{24}$ However, Brother Jonathan and Uncle Sam appear as separate entities in Civil War cartoons, and the absorption of one by the other is a later phenomenon. Most importantly, Columbia continues to represent the nation despite the presence of the two male figures.

Between 1861 and 1865, Uncle Sam appears twelve times in Harper's Weekly and thirteen times in Frank Leslie's Illustrated Newspaper. Brother Jonathan graces the pages of the two newspapers sixteen times and seven times, respectively. Due perhaps to editorial preference, and to the smaller number of political cartoons in Leslie's, there is a discrepancy between the number of times Columbia appears in the two publications. While she represents the nation only eight times in four years in Frank Leslie's Illustrated Newspaper, she appears thirty-one times in Harper's Weekly. ${ }^{25}$ The Lady Liberties, Columbias, and other female personifications that appear in poems and illustrations of the war participate in and respond to the conflict, just like actual American women. While Shirley Samuels insists that political allegory "at once embodies national conflicts and insists that we read past or through bodies," the close connection between the trials and triumphs of Columbia and her Southern sisters and the Civil War experiences of American women interferes with this process. Alternatingly belligerent, mournful, angry, indignant, and determined, the Columbias who appear on the pages of Civil War periodicals blur the line between the abstracted symbolic feminine and the lived experience of American women.

\section{Awakening Columbia}

Prior to the onset of war, Columbia watches with dismay as her children fight and divide into sections. As the mother of both halves of the country, her intact body invokes the relationship common to all Americans and the nation's vulnerability to division and fragmentation. In the cartoon Miss Columbia Calls Her Unruly School to Order (1860), Columbia appears as a schoolmarm tower- 
ing over her misbehaving children. ${ }^{26}$ Divided into North and South by a line labeled "Mason-Dixon," the classroom is full of men reading the Constitution. Holding a switch and wagging a finger, Columbia admonishes the men, many of whom seem to be ignoring her lesson. One of the men in the Southern section writes "Let us alone" on the wall. The cartoon responds to the growing sectional crisis by embodying in Columbia the nation as a whole and the importance of keeping the Union intact, underscoring her symbolic importance to conceptualizations of the nation. Significantly, Columbia is the only woman in the room; only male students squabble over the future of the nation. However, the symbolic feminine invokes the mothers of the nation - the women whose children will fight the quickly approaching war - and the investment of American women in the outcome of the sectional conflict. Columbia simultaneously indicates the absence of women from the halls of Congress while resembling the politically active women of the abolitionist and temperance movements. In doing so, she blurs the distinction between the domestic and the public in her efforts to bring together a nation divided by the Mason-Dixon line.

Columbia also acts as a seamstress, attempting to mend a damaged or ripped map of the United States, in her efforts to keep the Union whole. The cartoon Soon to Be Out of a Job (1860), published in Vanity Fair, portrays Columbia as the lady of the house informing "Biddy Buchanan" that her services will not be needed "after next March." ${ }^{27}$ Depicted as an Irish maid, President James Buchanan faces a Columbia seated in front of a standing man resembling Uncle Sam. Columbia stitches the two pieces of a map of the United States, one half labeled "North" and the other "South." As the wife and mother in this American family, Columbia is in charge of the domestic help, and she has deemed Buchanan unfit for office. Buchanan's Irish heritage and his inefficacy in the face of the sectional crisis make him fair game for the kind of ridicule often heaped on Irish Americans in the nineteenth century. The matronly "Mrs. Columbia," sitting beneath a bust of George Washington, attempts to do what Buchanan could not—-hold the nation together. Published prior to the 1860 election, the cartoon outlines the role of the next president: It will be his job to aid Columbia in reuniting the country. The cartoon domesticates the political, placing the symbolic feminine in charge of the future of the national house. Columbia's manual labor with needle and thread also foreshadows the handiwork necessitated by the impending conflict; soon, Northern and Southern women would serve the cause by joining soldiers' aid societies, mending socks, sewing uniforms, designing and producing battle flags, and making bandages. ${ }^{28}$

Lincoln replaced Buchanan in 1861, and the bombardment of Fort Sumter occurred soon after, Lincoln's hoped-for "better angels" failing to prevent war. Responding to secession, Columbia appears in Harper's Weekly on June 8, 1861, in the political cartoon Columbia Awake at Last. Garbed in the stars and stripes and backed by the spirit of George Washington, Columbia collars a diminutive man representing "secession" and "treason" [Figure 1]. ${ }^{29}$ The man, with an American flag and a palmetto (the state tree of South Carolina) protruding from 


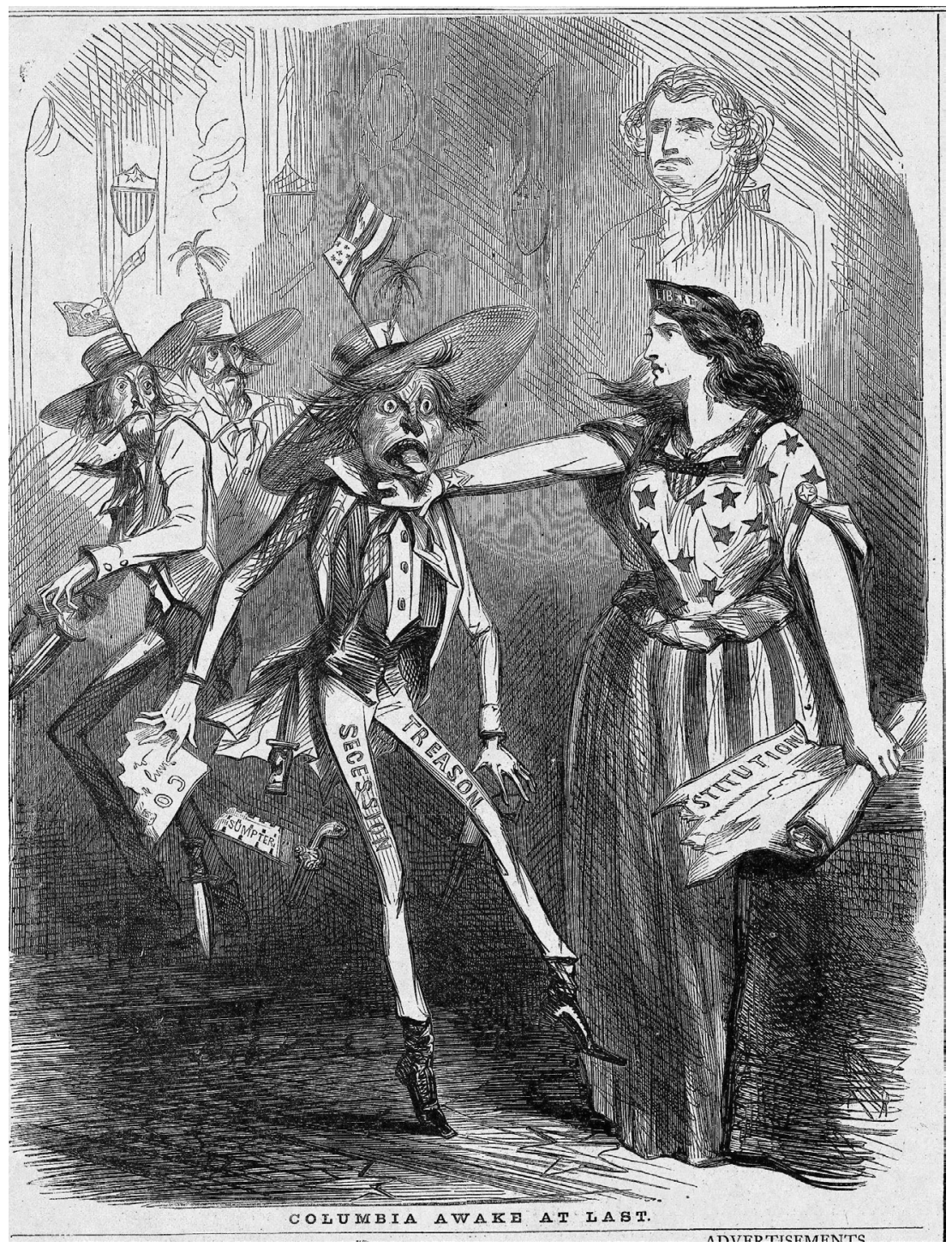

Figure 1: Columbia Awake At Last (1861), HarpWeek.

his hat, has torn a piece of the Constitution from the stately Columbia's grasp. A man with a skull-and-crossbones flag stuck in his hat and a man sporting a matching palmetto tree, representatives of the seceded Southern states, creep away from the intimidating woman. All three men carry knives, instruments clearly intended to injure Columbia and dismantle the Union. Roused by the firing upon Fort Sumter, Columbia is "awake at last" to the threat posed by secession. Though the seceding Southern states are armed, Columbia stands firm and 
appears ready to physically bring them back into the Union. The Southern states are male but scrawny and shrink from the physically impressive Columbia.

Written and published in 1861 and extremely popular throughout the war, James Ryder Randall's “My Maryland” imagines a similarly bellicose female personification. ${ }^{30}$ The poem, which was later set to music, was first published in The New Orleans Delta but appeared in many other Southern publications. ${ }^{31}$ Because the Confederacy is a new nation founded in state sovereignty, it often appears in the guise of one of its constituent parts rather than as a unified whole. While Columbia invokes unity and homogeneity, personifications of Virginia and Maryland reflect the primacy of the individual state in the face of encroaching federalism, a concept that is central to Confederate wartime rhetoric. A secessionist citizen of Baltimore, Randall employs a familial metaphor to portray his home state as a threatened and embattled mother/sister and encourages her and her sons to rise to the occasion. ${ }^{32}$

In its deployment of the symbolic feminine, Randall's poem invokes the threat of Northern tyranny, beginning, "The despot's heel is on thy shore, Maryland!/His torch is at thy temple door, Maryland!" Appealing as a "wand'ring son" to his "Mother-State," Randall's speaker establishes the familial ties that bind him to his homeland. These ties extend to the states of the Confederacy, and the speaker calls on his mother to join her sisters: "Dear Mother! burst the tyrant's chain, Maryland!/Virginia should not call in vain, Maryland!/She meets her sisters on the plain." If Maryland fails to resist "the Vandal," she will suffer "crucifixion of the soul." The Northern invaders threaten the purity and chastity of the motherland, but the poem ends optimistically. "She is not dead," Randall's speaker avers, "nor deaf, nor dumb-/Huzza! She spurns the Northern scum!/She breathes — she burns! she'll come! she'll come!" Facing bodily harm and physically engaged in the process of disunion, Columbia and Maryland similarly reflect the vulnerability of American women's bodies while indicating the possibility of female mental and physical participation in the war itself.

\section{Petulant Children and Maternal Love}

Southern poets, Northern poets, and Lincoln himself rely on the familial metaphor to frame the national conflict. ${ }^{33}$ Significantly, the concept of a house temporarily divided emphasizes the possibility of future peaceful reconciliation. While Northerners can conceive of individual Confederate states as estranged sisters that resist or betray the family ties that bind the Union together, Southerners can imagine a confederation of autonomous sister states as a new model for nationhood. Removed from the violence of the battlefield, female personifications enable Northern poets to engage in nonviolent apostrophes to misbehaving members of the national family. Published in The Atlantic Monthly in May 1861, the month following the bombardment of Fort Sumter, "Brother Jonathan's Lament for Sister Caroline" is Oliver Wendell Holmes's rendition of the growing sectional crisis. ${ }^{34}$ Employing the conceit of a brother appealing to his delinquent 
sister, the poem allows for the eventual reconciliation between siblings. "She has gone," Brother Jonathan begins, "she has left us in passion and pride,-_/Our stormy-browed sister, so long at our side." The first state to secede, South Carolina is the defiant sister of Holmes's poem, who "has torn her own star from our firmament's glow,/And turned on her brother the face of a foe!" By May 1861, eleven states had followed South Carolina's lead and seceded from the Union. Commenting on the defiance of the seceding states, Jonathan asserts, "Nature must teach us the strength of the chain/That her petulant children would sever in vain." Imagining South Carolina as a "hasty" and "rash" female ensures that "there are battles with Fate that can never be won." The Union's children will return to the family, and the firmament will have all its stars once again.

A pair of poems, titled "Two Pictures of the South" and printed in The Liberator on July 5, 1861, illustrates competing renditions of the maternal feminine. ${ }^{35}$ William Gilmore Simms's "Song of the South," originally published as "Oh! The Sweet South" in The Southern Literary Messenger issue of January 1,1861 , appears beside a parody of the poem. Simms, a popular writer and editor, produces a paean to "the sunny, sunny South" that establishes the "land of true feeling" as his mother and, at times, his lover. Simms's speaker extols the South's virtues and avers, "She brings me blessings of maternal love." G.E.D.'s parody mimics Simms's poem formally and uses similar and at times identical language. However, the parody denigrates the South, "Land of slavery, land of wails and wo $[s i c] . "$ Rather than mothering her children, the South "brings ... tears from the maternal eye" and "sunder[s] kin." Changing the first line of the second section of Simms's poem from "Oh! love is hers" to "Ah! Hate is hers," G.E.D. focuses on a topic unmentioned in Simms's laudatory poem. G.E.D.'s speaker invokes the captive lives and battered bodies of African American slaves, indicating the reason for his rejection of Dixie: "Oh! by the fate of the unhappy blacks, - - OOh! by the cruel blows, and broken ties, - - And by their groans and lacerated backs,- - By these, and more, that loud for vengeance cries." G.E.D. rejects Simms's personification of the South as mother, lauding instead "the inclement clime/Where Freedom reigns sublime." Read together, the two poems illuminate the rhetorical war raging alongside the actual war. The Southern maternal personification, G.E.D. claims, is a mother who brings death rather than life, shadow instead of sunshine. A new birth of freedom, ushered in by swift Northern victory, will destroy Simms's South and restore the Union as the only true mother.

\section{A Stigma Rests upon Her Frame}

As the war persists despite initial Northern confidence in a short and successful campaign, vulnerable Columbias reflect growing concerns about continued disunion and Southern invasion. After the South's initial betrayal of the national mother, ongoing treason threatens to dismember and degrade her body. It is the duty of her Northern sons, a number of poems imply, to arm for war and to 
sacrifice their bodies so that Columbia remains whole. Similarly, female personifications of Confederate states align the Southern war effort with the protection of female chastity and the cause of freedom in the face of tyranny. At once virginal and motherly, Columbia and her Southern sisters must rely on male action to remain nationally and sexually intact. This poetic construction ties nationhood to female purity, thus invoking the threatened bodies of real women but also reducing feminine participation in the conflict to figurehead status.

In two poetic calls to arms, "Our Country's Call" (1861) and "Not Yet" (1861), William Cullen Bryant imagines a helpless Columbia threatened by treasonous foes. ${ }^{36}$ "Our Country's Call," the desperate cry of a beleaguered woman, urges the men of the North to "lay down the axe" and pick up a rifle, the pitiable state of the Union necessitating the transformation from farmer to soldier. "See," Bryant's speaker instructs his readers, "from a thousand covertssee,/Spring the armed foes that haunt her track;/They rush to smite her down, and we/Must beat the banded traitors back." Preyed on by her enemies, the nation is vulnerable and in need of male protection. In "Not Yet," Bryant rejects the notion of dissolution and disunion, declaring that those loyal to the Union will save her. "Shall we," his speaker asks, "like cravens stand apart,/When those whom thou hast trusted aim/The death-blow at thy generous heart?" Traitorous Confederates, seeking to kill their motherland, impel "hosts [to] rise in harness, shouting, No!" The "sleeping ashes" of the founding fathers also reject the breaking of "gentle ties which long/These sister States were proud to wear." Invoking motherland, founding fathers, and sister states, Bryant urges Northern men to once again join together to protect the American family. In doing so, he relies on familial metaphors to indicate the stakes of the conflict and invokes the power of patriarchal society to protect female and national purity.

As national mother, Columbia bears the national shame of the peculiar institution, her purity tainted by her relationship to slavery. Male action, poets insist, will remove the twin taints of treason and slavery and maintain the physical integrity of American women and the nation. T. Hulbert Underwood and Laura Redden Searing create guilty but powerless female personifications of a fundamentally flawed nation. Published two months after Bryant's "Not Yet," Underwood's poem "Now" (1861) is an answer to Bryant's rhetorical question and an indictment of Columbia's association with slavery. Mirroring Bryant's poem in form and content, "Now" asserts that the nation has already been brought low. "The traitor's arm has laid her low," but her own "statesmen" must also be held accountable for her sorry state. It is they who failed "to 'tear' from Slavery its mask,/And drive it from its cherished lair." Allowing the "dragon" of slavery to grow strong, America's leaders "left a curse to after-time." Underwood twice depicts the nation as physically marked by the sin of slavery and the war fought to end it: "A stigma rests upon her frame" and "the fire of civil war to-day/Has charred upon the Nation's brow/A brand no tears can wash away." For past sins, the nation and her people suffer the wrath of God. This wrath is evident in the Potomac's "ensanguined flow" and on the figurative form of Columbia. Actual 
female bodies are absent from the poem, leaving only the suffering of soldiers and symbolic femininity as indications of the struggle's effects.

Written a year later, Searing's poem "The Legend of Our Victories in '61'62," published under the pseudonym Howard Glyndon, portrays the Union as a Hester Prynne-like figure, physically marked by wrongdoing: "Too long this fair young kingdom,/The Empire of the West,/Had borne a blasting stigma/ Upon her virgin breast!" ${ }^{37}$ Despite Searing's soaring rhetoric labeling the democracy both monarchy and empire, the symbolic importance of the Union's virginity is clear. The Union army's victories remove the stain of sectional strife and keep the Union pure by protecting "our women and children." Searing expresses a similar sentiment in "Union Forever" (1864) a poem that addresses the "men of America," calling on them to "press to [their] standard." ${ }^{38}$ Searing's speaker invokes Columbia, lamenting her imperiled state: "How art thou fallen, O Daughter of Promise!/From the throne of thy lofty and virgin estate/When thy children are drunk with the blood of thy suffering,/And traitors are ringing the knell of thy fate!" Besmirched by dissension, the Union must be restored by "a band of the staunch and devoted,--Men whose integrity never was bought." In both poems, Searing employs the language of sexual purity to call the sons of the Union to action. Like Bryant and Underwood, Searing indicates male action as the cure for the nation's woes, leaving actual women out of the equation.

Published in The New South, a Unionist paper in Port Royal, South Carolina, Charles A. Barry's poem "Columbia's Invocation!" (1862) also depicts a stained Columbia, one who "wash[es] out with tears/And hero-blood, her only shame." ${ }^{39}$ Northern victory, according to Barry, will serve to cleanse the nation of its $\sin$ - chattel slavery. The beleaguered nation, menaced by "gathering foes," addresses the American flag, asking it to "wave o'er [her] people as they rise/To win [her] back [her] fame again." Barry's speaker calls on "freemen," urging them to "smite to kill" in defense of their suffering nation. "See!" the speaker exclaims, "Freedom bleeds!/She calls you with her stifled breath:/Rebellion to her Temple speeds-/March on, to Victory or Death!" As a personification of the nation and of freedom, Columbia's survival depends on male action. Implicit in Columbia's suffering is the threat to actual women, those who are vulnerable to the encroaching conflict or are asked to sacrifice their sons, brothers, and husbands. Also implicit, however, is the actual physical labor of women. An estimated 20,000 women worked in Northern and Southern hospitals, many of them as laundresses. ${ }^{40}$ Constantly in contact with "hero-blood," these women contributed to the war effort in a tangible manner.

\section{Somewhat in the Background}

Despite such contributions, depictions of symbolic femininity far removed from the war proved persistent. Published in Southern Punch, a paper modeled on the popular London periodical, the cartoon Abduction of the Yankee Goddess of Liberty (1863) portrays a besieged female personification at the mercy 
of a devilish figure [Figure 2] ${ }^{41}$ However, Lady Liberty suffers not at the hands of Confederate foes but, instead, in the clutches of the arch-Yankee. Abraham Lincoln, in the guise of "the prince of darkness," absconds with the goddess, taking her to "his infernal regions" in order to silence her "preaching about the Constitution." Claiming that he was "the first to rebel against constituted authority," Lincoln resembles Milton's archfiend Lucifer-the president, not the Confederates, upsets the national balance of power and threatens to destroy liberty. Echoing Shakespeare's power-hungry and murderous Lady Macbeth, Lincoln informs Liberty that "hell is murky." ${ }^{\text {42 }}$ His forked tail, which emerges from behind the goddess' waist, poses a sexual threat while his fiendish plans seek to destroy the core values of America. Northern tyranny, the cartoon implies, desecrates the very ideals it claims to protect. The Southern artist deploys the symbolic feminine (one that closely resembles Northern visual depictions of Columbia but does not bear the national mother's name) in order to claim Lady Liberty for the Confederate cause and to align Southern success with the protection of helpless femininity.

Columbia confronts the arch-Confederate, a devilish Jefferson Davis, in Check-Mate! the cover illustration for the June 3, 1865 issue of Harper's Weekly [Figure 3]. ${ }^{43}$ The illustration mimics Moritz Retzsch's 1837 engraving The Game of Life or The Chess-Players, a depiction of a young man playing chess with the devil. The accompanying text explains that Davis, "the Spirit of Treason," is "playing with Uncle Sam for his Life." Uncle Sam, "the type of calm, self-possessed manhood," faces the "Prince of Rebellion" with a "countenance expressive of triumph tempered by amiability." Dressed like the Devil in Retzsch's engraving, Davis embodies "all the rapacity of a Tiger and all the cruelty of a Hyena." The description continues:

Between the two players, somewhat in the back-ground, stands a gentle, lovely angel-form, with white and outspread wings - the GODDESS OF LIBERTY, the protecting spirit of Uncle Sam, but not seen by him. She looks in rapture down upon the victorious termination of the struggle. But now let us look again at the game itself. (337)

A silent and invisible presence, Liberty is removed from the actual contest-a separation made even more evident by the rhetorical return to the "game itself." Grant is the king on Uncle Sam's side and "the Queen is COLUMBIA, a lofty, majestic figure, unfurling her vindicated flag." Her position on the board "supports the more active officers." Even though Columbia is part of the game, she is not an active officer, and it is Uncle Sam (the representative of the government) that moves her around the board. Removed from the actual process and progress of war, the figures of Columbia and Liberty invoke the allegorical significance of femininity while excluding actual women from the national "game"- the political moves that led to the Civil War and the conflict that resulted. 


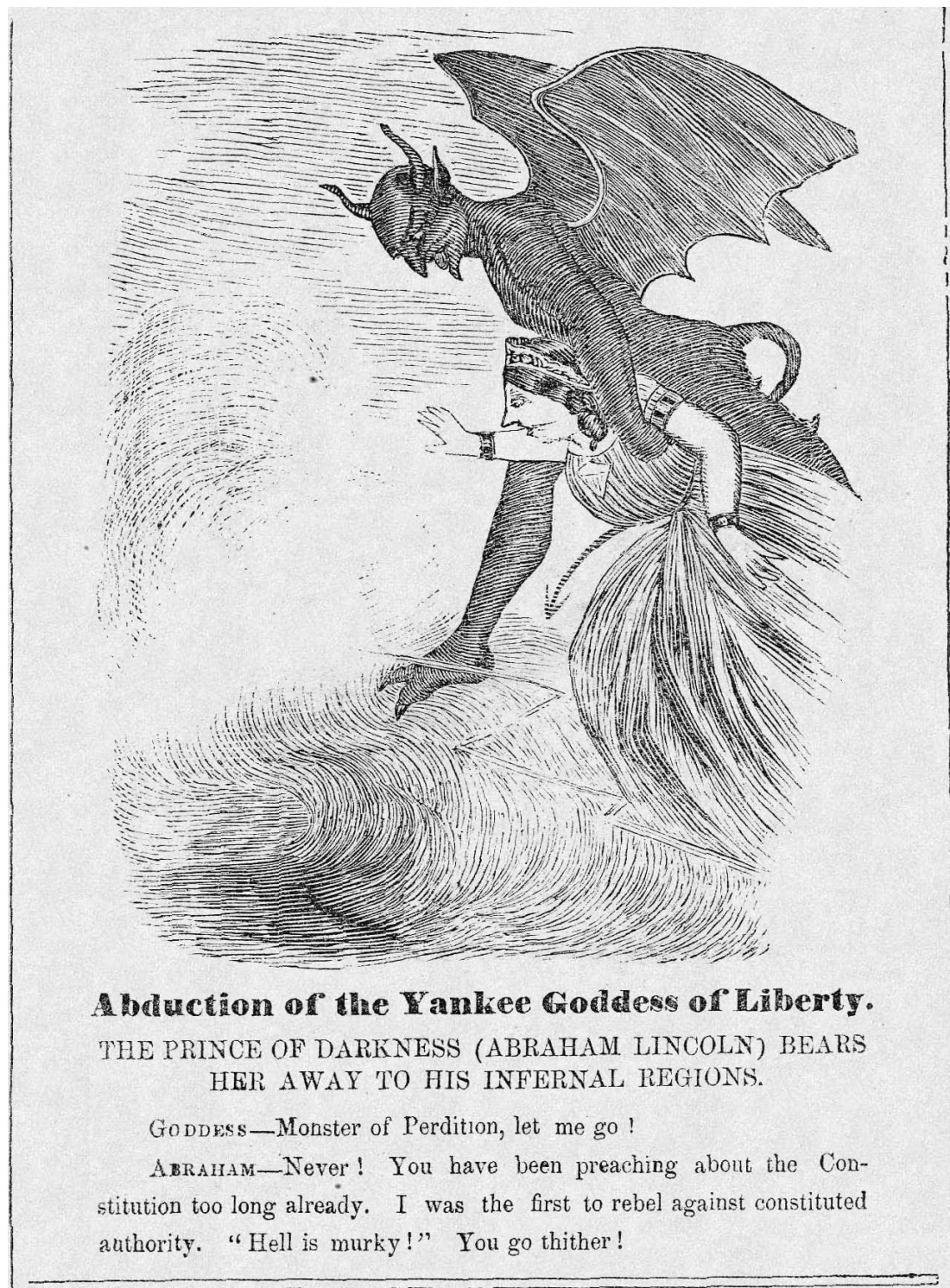

Figure 2: Abduction of the Yankee Goddess of Liberty (1863), HarpWeek.

Despite the lingering presence of the helpless and removed symbolic feminine, Columbia acts as the sponsor of Union combatants during and after the war. In doing so, she indicates the steadfast devotion of American women to the cause and to the well-being of soldiers and also performs a public and political role. Two certificates, one published in 1861 and the other in 1863, indicate 


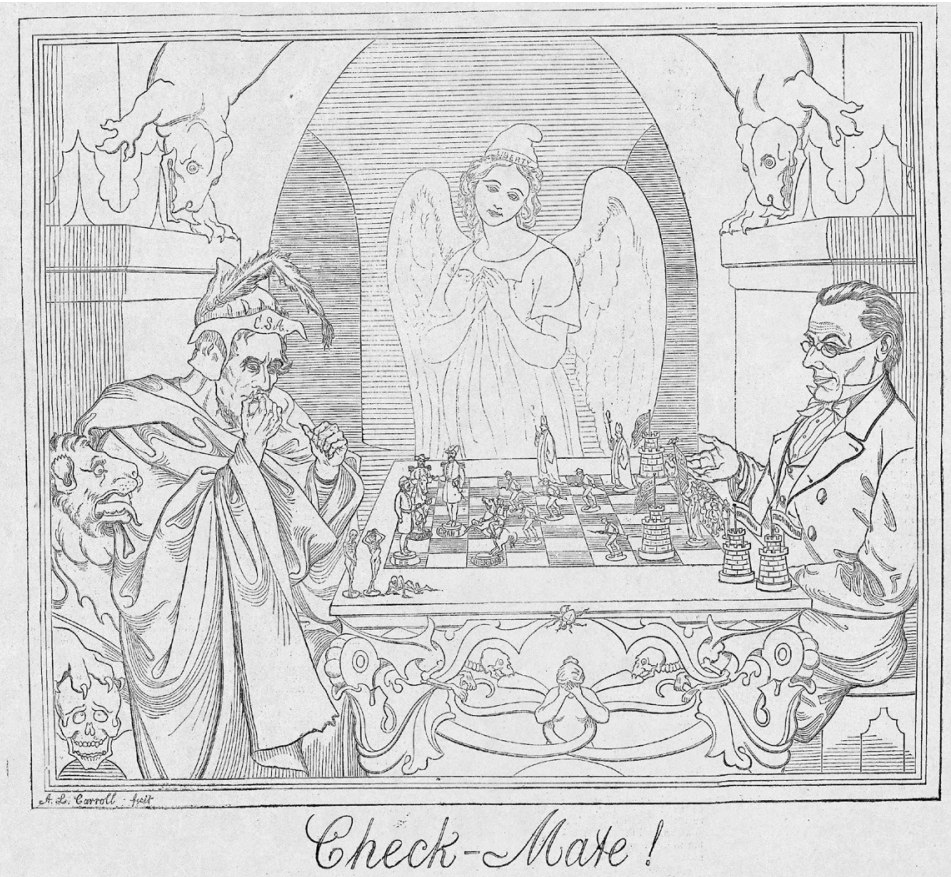

Figure 3: Check-Mate! (1865), HarpWeek.

this trajectory by closely associating Columbia with the defenders of the Union. In Defence of the Union and the Constitution (1861) certifies that the recipient of the award fought "in support of the Government to suppress the rebellion of 1861." ${ }^{44}$ The Union Defenders Certificate (1863) acknowledges the recipient's service in defense of the "government, the Union, and the Constitution" [Figure 4]. ${ }^{45}$ Both certificates predominantly feature Columbia, portraying her as the representative of the Union the soldiers fought to save and the patron saint of the men who waged war in her name. On the first certificate, Columbia holds two laurel wreaths over a soldier's head and extends her star-spangled robe to shelter a woman crouching with her children, rewarding the soldier and looking after his family. The second certificate displays Columbia in the forefront of the image, raising the American flag and pointing to a battlefield. She looks over her shoulder, urging the viewer to recognize the service and sacrifice of her defenders.

After demoralizing and costly Union losses, Columbia vehemently advocates for her defenders and her fallen children. In doing so, she does more than commemorate Union soldiers - she publically demands answers, protesting the violent deaths of her sons as well as publically performing the grief and frustration of bereaved women. In two political cartoons, a belligerent and infuriated Columbia confronts Lincoln regarding the deaths of her soldier sons. Published 


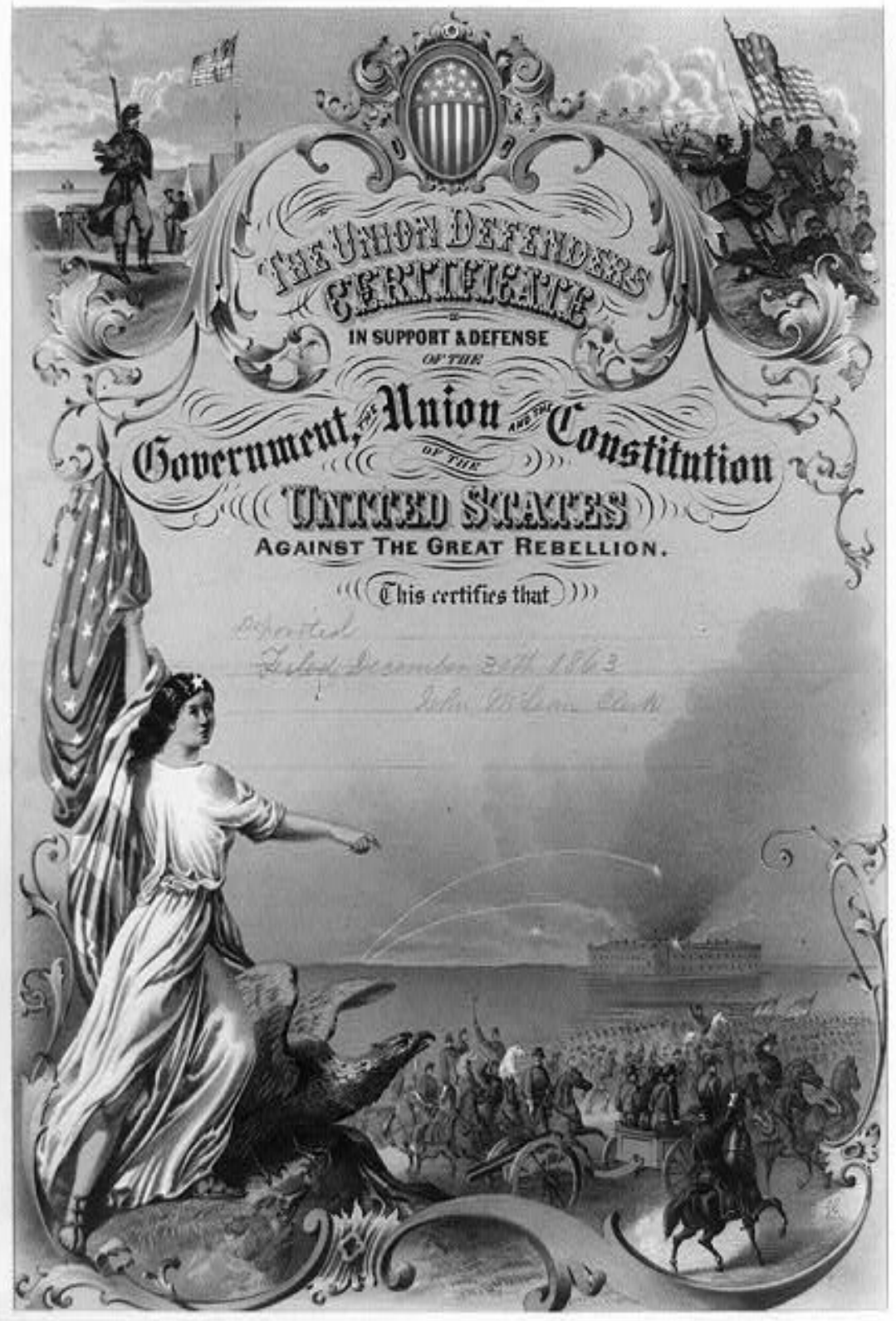

Figure 4: The Union Defenders Certificate (1863), Prints and Photographs Division, Library of Congress, LC-USZ62-90747. 
in Harper's Weekly in 1863, Columbia to Lincoln features an intimidating and accusatory Columbia pointing her finger at the president. ${ }^{46}$ "Where are my 15,000 sons, murdered at Fredericksburg?", she demands, and rejects the joke offered by the notoriously wise-cracking president. During the battle of Fredericksburg, disastrous frontal attacks against entrenched Confederates led to devastating Union casualties. Columbia's indignation reflects public sentiment about the battle and indicates female engagement with the course of the war and the political and military decisions made by men. In the 1864 cartoon Columbia Demands Her Children!, Columbia, again pointing an accusing finger, rejects the president's call for 500,000 volunteers, demanding that Lincoln "give [her] back [her] 500,000 sons [Figure 5]. ${ }^{47}$ In both cartoons, Columbia protects the interests of her sons, rejecting the avoidable slaughter at Fredericksburg and Lincoln's call for more men. As protester and public representative for Union soldiers, Columbia enters the national arena.

\section{Her Self-enwoven Fetters Shake}

Women abolitionists were very much part of the sectional crisis leading up to the Civil War and remained active in the public arena during the conflict and after emancipation. Reformers and activists such as Susan B. Anthony and

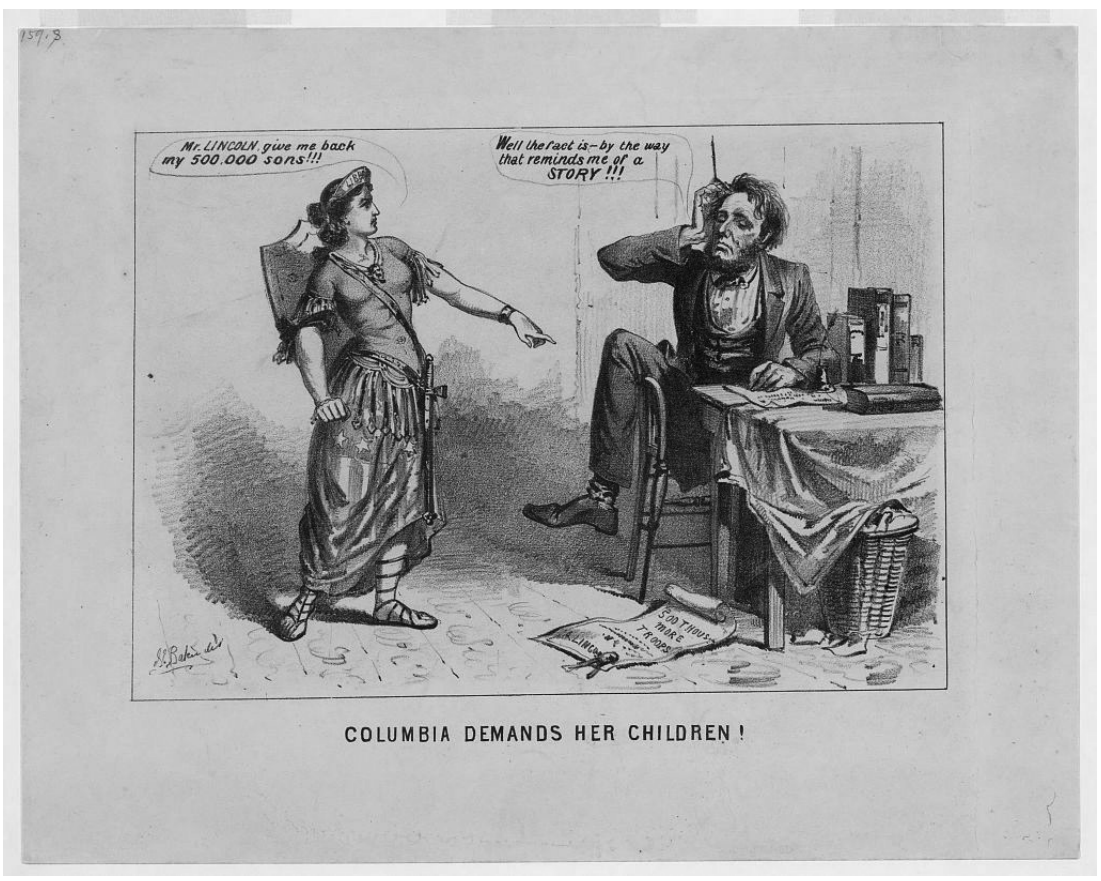

Figure 5: Columbia Demands Her Children (1864), Prints and Photographs Division, Library of Congress, LC-DIG-ppmsca-15768. 
Elizabeth Cady Stanton sponsored petitions for an emancipation amendment and worked closely with hundreds of thousands of Northern white women, many entering the public realm for the first time, to abolish slavery. ${ }^{48}$ Free black women formed antislavery organizations and auxiliaries to the American AntiSlavery Society, the nation's preeminent abolitionist group. ${ }^{49}$ Northern poets and artists depict the relationship between the work of real women and the end of slavery by deploying the symbolic feminine, Columbia, who, as Northern victory becomes more and more aligned with abolition, breaks the fetters of bondage and acts as an agent of emancipation.

Poets describing the nation as shackled and fettered echo abolitionist poems describing the horrors of slavery and thus connect the body of the Union to the bodies of the slaves. William Lloyd Garrison's song for the Anti-Slavery Celebration at Framingham, Massachusetts, "Our National Visitation" (1862), describes Columbia's punishment for "her manifold transgressions." ${ }^{50}$ God's wrath leaves the nation "scourged and torn," her "glory" departed. Garrison argues that Columbia herself "has forged the galling fetter." Columbia divests herself of her chains in the poem "National Ode: Suggested by the President's Proclamation of January 1, 1863" (1863).$^{51}$ Responding to the Emancipation Proclamation, the poem urges, Columbia must "awake,/Her self-enwoven fetters shake,/And vivify the pulses of the land!" The "slimy coils" of slavery encircle Columbia's white limbs only; significantly, the poem references the "black, blank faces" of the slaves only once. The song and poem rely on the white female body for its rhetorical power rather than depicting "scourged and torn" slave bodies. In this way, both blur the boundary between black and white (since a white body can be fettered) while reinforcing the racial hierarchy.

While the national sin shackles Columbia, Northern invaders threaten to enslave Southern womanhood. The song "Maryland in Fetters!" (1861), published as a broadside, laments the pitiful condition of the "Mother of wretchedness," implying that defeat will be tantamount to rape and enslavement. ${ }^{52}$ The description of the beleaguered state is in stark contrast to the image printed on the broadside [Figure 6]. The female figure carries a scale, a sword, and an olive branch. At her feet are fasces similar to ones often carried by Columbia. The figure is most likely a combination of Lady Justice and Columbia and reflects a commonality between Northern and Southern representation of the symbolic feminine. However, the title and focus of the poem underscore the primacy of Maryland as an individual and threatened state, rejecting the notion of an all-encompassing federal feminine symbolic. Addressing the state, the speaker laments, "The spoiler's foot upon thee,/His ruthless hand is on thee,/With manacles he's bound thee,/Hard is thy fate!" The upheaval of the war and the threat of Northern invaders, the song implies, has upset the social and political order - white womanhood suffers the shackles of slavery. The song ends with a vehement decree: "Let Lincoln know his place,/Let black men know their face,/ And from our injured race/All wrongs be riven." One of these "wrongs" is the degradation and enslavement of Maryland herself. Black men, the poem seems 


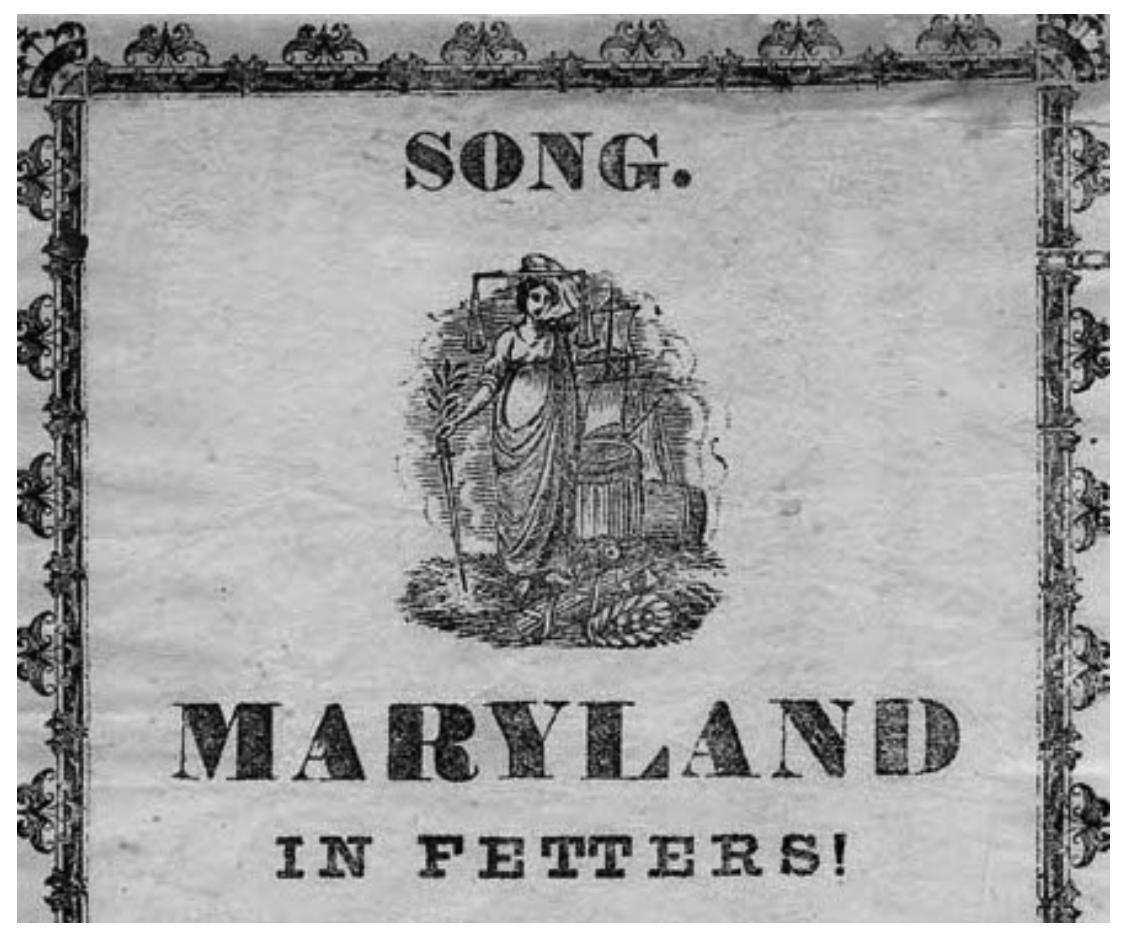

Figure 6: Illustration from "Maryland in Fetters" (1861), Special Collections \& University Archives/Wake Forest University.

to argue, and not the white female personification of the state, should be shackled. Maryland's freedom is contingent on the perpetuation of the institution of chattel slavery-an institution that shames and stains Maryland's Northern personified counterparts.

Despite Columbia's symbolic complicity in the rise and spread of slavery, she also appears as the champion of the freedmen and the arbiter of justice. Two poems published after the Emancipation Proclamation, "The Promise Must Be Kept" (1864) and "November 8, 1864" (1864), envision Columbia as a defender of freedom and advocate for the total abolishment of slavery. Published in the New York Tribune and The Liberator, the former is an answer to opponents of the Emancipation Proclamation seeking to revoke the promise of freedom. The freedom-wielding nation rejects cries to "degrade the proclamation": "See on her sacred shore Columbia stand,/While broken chains lie "round her on the strand,/And hear her cry to every down-trod land:/'BEHOLD A NEW CREATION!'” The motherland seemingly gives birth to freedom for the slaves, a poetic conceit which ostensibly limits femininity to reproductive capacity. However, Columbia destroys the chains that bind her, a labor that moves beyond the restricted role of maternity and into the political and societal realm. 
"November 8, 1864" (1864), a poetic celebration of the re-election of Abraham Lincoln, imagines an even more powerful Columbia. ${ }^{53}$ The speaker describes a vision inspired by the election: "I see bold Freedom with a giant's stroke/ Hurl to the earth the bondman's heavy yoke;/I see her strike from off his horny hands/The galling chains and fetters where he stands." Columbia, personified in this iteration as Freedom, is the agent of emancipation. She breaks the chains of the bondman, an act that serves as a harbinger of eventual Union victory.

An allegorical depiction of this victory, the illustration The End of the Rebellion in the United States, 1865 (1866) gathers together three closely connected and often interchangeable female personifications: Justice, Liberty, and Columbia [Figure 7] ${ }^{54}$ Columbia and Liberty stand upon an altar while Justice, sword in hand and backed by the newly inaugurated Andrew Johnson, strides toward recalcitrant Confederates. General Ulysses S. Grant leads a vanguard of Union soldiers to meet the surrendering Robert E. Lee and his beleaguered troops. In the forefront of the illustration are an African American soldier and a freed slave. The latter kneels in front of the altar, gazing up at the two figures upon it. Columbia, her eyes on the black soldier, gestures to the freed slave, seemingly displaying to the soldier the results of his service. The only female figures in the image, Columbia, Liberty, and Justice represent the ideals protected by the soldiers of the Union and the martyred President Lincoln. The three white female figures form the focal point of the illustration, one devoid of any black women, and Northern and Southern men appeal to their majesty.

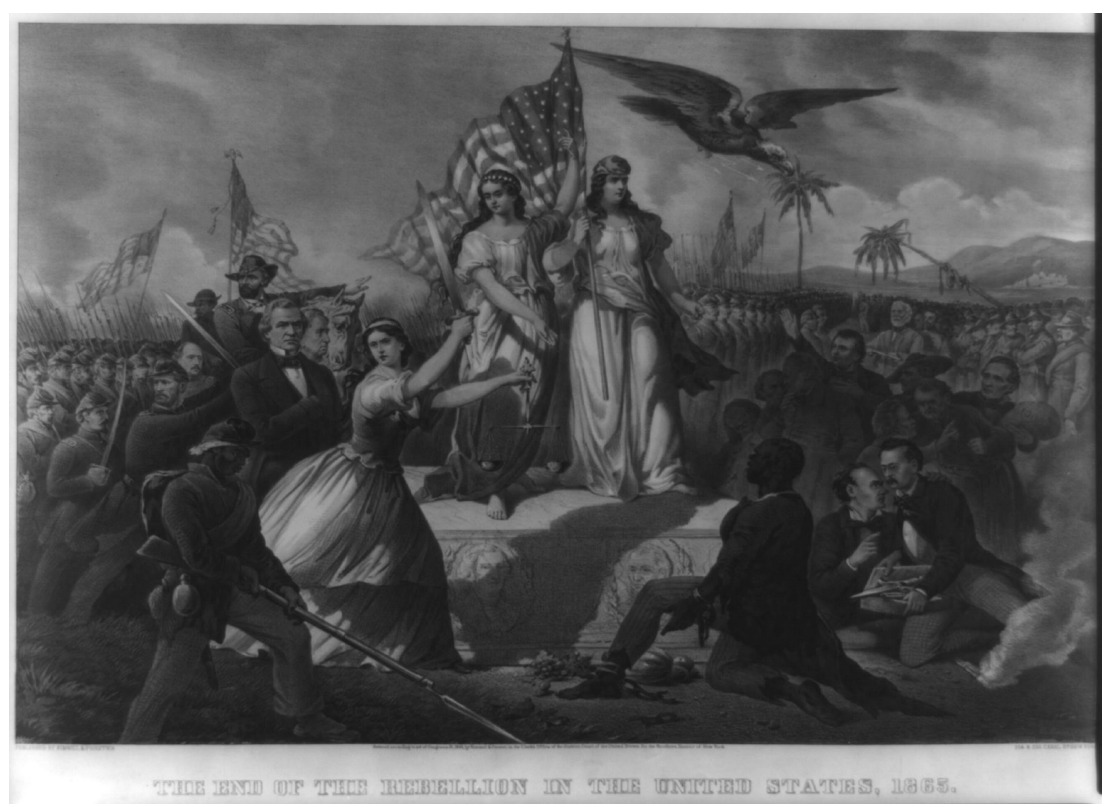

Figure 7: The End of the Rebellion in the United States, 1865 (1866), Prints and Photographs Division, Library of Congress, LC-USZ62-12764. 
While Columbia and Liberty wear loose-fitting white robes, Justice dresses like a contemporary woman, her feet on the ground instead of an altar as she leads the charge to bring former rebels to justice. In this way, Justice aligns symbolic femininity with actual (white) female agency and potentially alludes to the political and social activism of Northern women.

\section{Kneel, Motherland!}

At times a stand-in for female action in the public arena, Columbia, as national maternal figure, also enacts the private grief of thousands of mourning mothers, wives, daughters, sisters, and lovers. She serves as chief mourner of her fallen sons and embodies the collective grief of the nation at the death of President Lincoln. The mother of the country makes mourning, a usually private and domestic undertaking, public and, at times, political, binding her children's wounds and reconciling them to living in the same house again. Mourner, peacemaker, and bearer of the memory of the war, Columbia enacts the duties of American women in the aftermath of Northern victory, Southern defeat, and the abolition of slavery. As noncombatants, women were responsible for remembering and commemorating their dead husbands, sons, and brothers. Doing just that, women draped themselves in black, claimed the bodies of loved ones, and decorated graves, becoming what, in its Confederate manifestation, Drew Gilpin Faust labels a "uniformed sorority of grief." 55

Columbia's role in the process of commemoration necessarily begins before the conflict's denouement, as casualties mount and the Union wins and loses battles, but becomes increasingly prominent after Northern victory. Before Southern surrender, Columbia's grief often serves as a rallying cry for continued dedication to the Union cause. Poets and illustrators invoke her tears, deploying the suffering symbolic feminine in order to indicate the necessity of continued bloodshed. "The Soldier's Grave" (1862), a poem published in a Unionist paper in Kansas, imagines a more intimate scene in which Columbia mourns an individual soldier's death. ${ }^{56}$ Addressing the soldier, the poem's speaker informs the young man that his country mourns specifically for him: "Rest, soldier, rest! thy country comes,/With tender love and true,/Freely to deck thine honored head-/Her banner o'er its turf to spread,/And on thy lonely grave to shed/Fond memory's pearly dew." As the chief mourner of the nation, Columbia grieves for each individual soldier who dies to protect her, just as actual women grieve the loss of their family members and husbands. Hoping to encourage other young men to make the same sacrifice, the speaker requests that the soldier throw his "mantle from the sky" so a "rising race" of American men will come to the country's defense "and in Jehovah's armor strong,/Her life, her Union save!"

Two of Thomas Nast's engravings, both published in Harper's Weekly, further illustrate the political cachet of symbolic feminine suffering. Honor the Brave (1863) features a mourning Columbia who, with head bowed, places a 
laurel wreath on a flag-draped coffin [Figure 8]. ${ }^{57}$ The border surrounding Columbia depicts soldiers and sailors "on land" and "at sea" who fight to protect the central figure. Beneath the main title are the words "The Union must and shall be preserved." The illustration establishes both the importance of saving the Union and the severe cost of doing so. Columbia simultaneously honors the children who have sacrificed their lives to defend her and calls on her sons to continue the fight. Compromise with the South (1864), published two months before the presidential election, deploys Columbia's grief to portray the dire results of voting Democrat. ${ }^{58}$ Columbia kneels weeping in front of a grave "in memory of the Union heroes who fell in a useless war." A Union veteran with an amputated leg bows his head as he shakes the hand of a Confederate soldier who stands with his boot upon the grave. To his rear, a family of slaves are chained together. The message of the illustration is clear: a Democratic victory will lead to the betrayal of every Union soldier who died or was wounded to protect the Union, the degradation of Columbia, and the continued enslavement of African Americans. Columbia's mourning calls on Northerners to reject compromise with Copperheads and Peace Democrats and to continue the war until total victory is achieved.

The illustration Abraham Lincoln's Coffin (1865), also published in Harper's Weekly, portrays another kneeling Columbia placing a laurel wreath on top of the president's resting place and covering her face with her hand [Figure 9]. ${ }^{59}$ To the left and right of Columbia, divided from her by a white border, a soldier and a sailor, defenders of the Union, bow their heads in grief, covering their

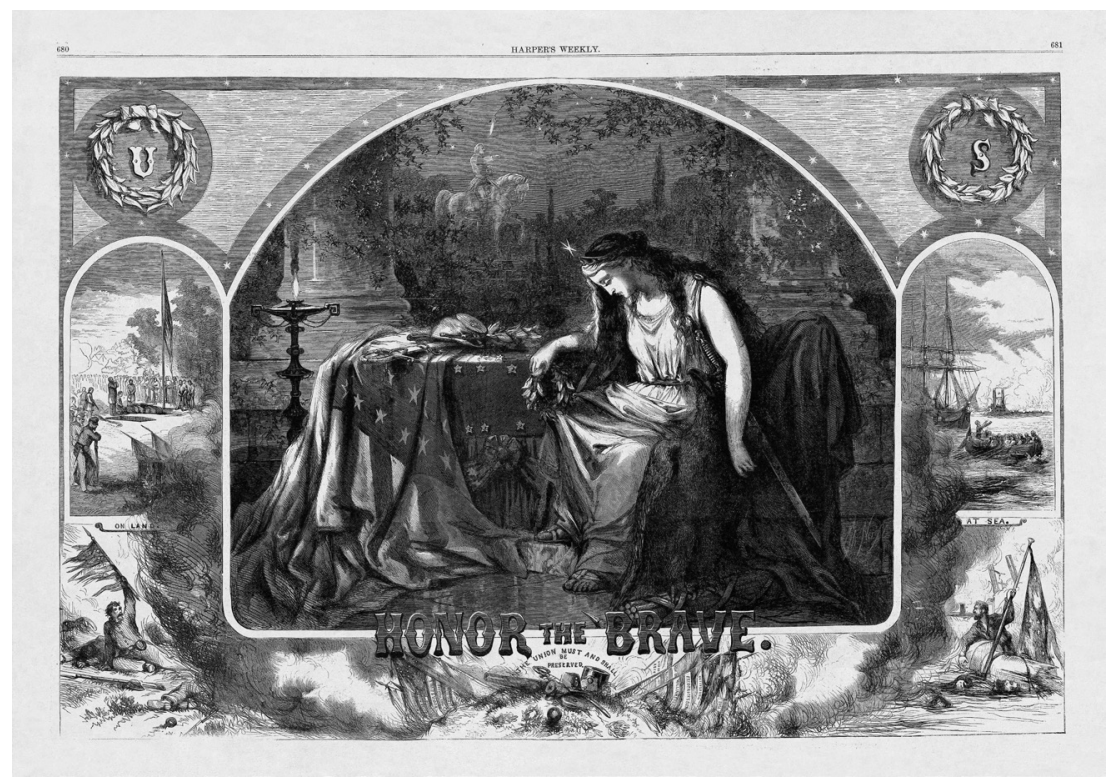

Figure 8: Honor the Brave (1863), HarpWeek. 


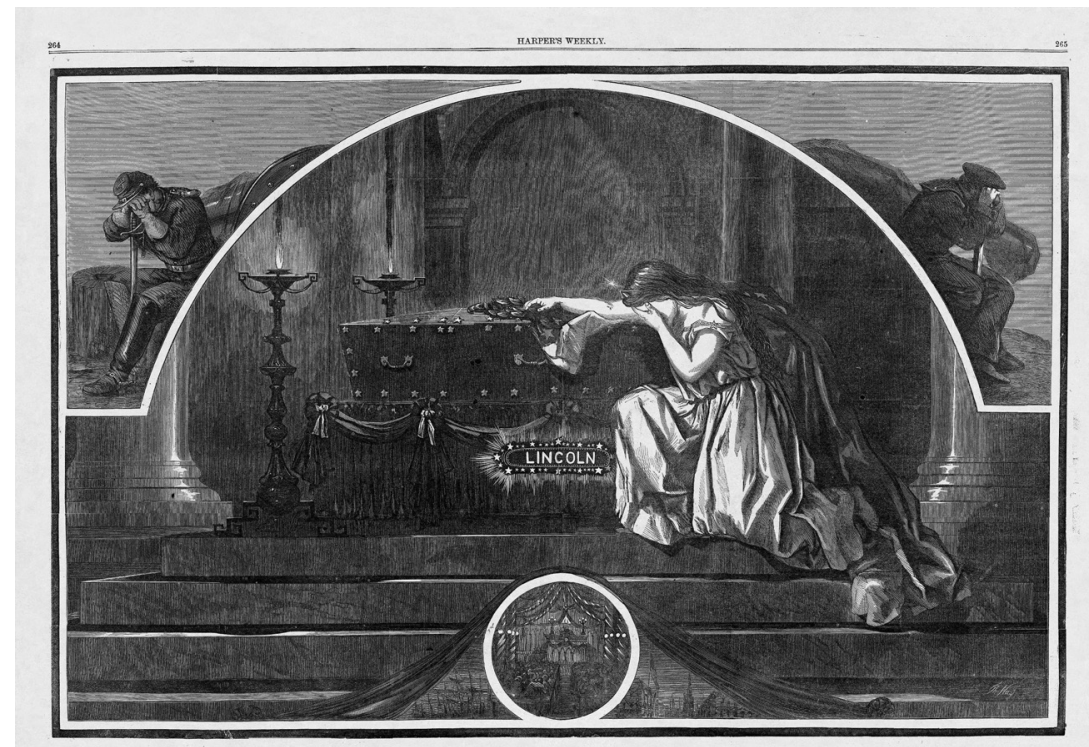

Figure 9: Abraham Lincoln's Coffin (1865), HarpWeek.

faces in a gesture that matches Columbia's as feminine and masculine mourning combine to embody the collective grief of the nation. "A Dirge-April 15, 1865," a poem published in The Liberator a month after the cessation of hostilities, also indicates Columbia's central role in the process of mourning Lincoln. ${ }^{60}$ The poem begins with a description of the nation's response to the president's death: "There's wailing from a million hearts - there's gloom on every hearth;/ The shouts of victory are dumb - hushed is the sound of mirth." In the midst of this collective outpouring, "the Nation, in black robes of woe, sits watching by her Dead!" Watching along with Columbia is "that dusky race, whose chains of slavery/He broke." Lincoln, the savior of the nation and the emancipator of the slaves, undergoes an apotheosis. Watched over by Columbia, his body takes on symbolic significance and, along with Columbia, demands that the nation deal fairly with the freedmen. Columbia, as the national maternal, will continue to mourn the fallen president and to encourage the reunited states to worship him and "follow where LINCOLN's footsteps led."

Similarly, a sisterhood of symbolic feminine figures in Thomas Nast's illustration Our Arms Victorious (1865) announces Lincoln's place in the nation's pantheon [Figure 10] ${ }^{61}$ In the center of the illustration are five toga-wearing figures gathered around a bust of Lincoln upon a pedestal. Justice holds her scales and sword while Victory places a laurel wreath upon Columbia's head and gazes adoringly at a toga-wearing and laurel-wreathed Lincoln. Sheathing her sword, Columbia rests her foot upon a cowering male figure draped in a robe labeled C.S.A. Perched next to Columbia is a freedman, a broken shackle at his 


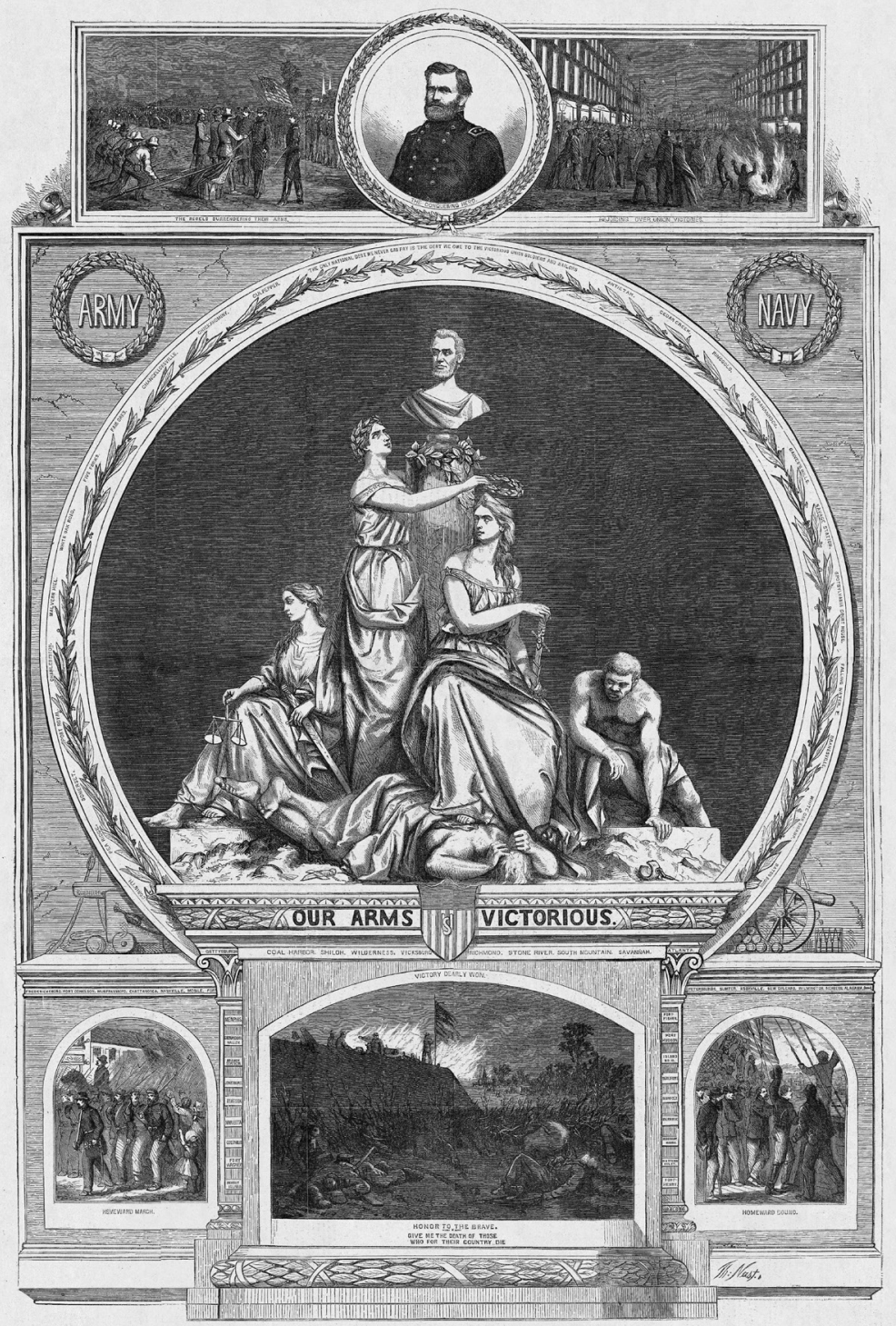

Figure 10: Our Arms Victorious (1865), HarpWeek.

feet. The illustration aligns the symbolic feminine with martial, judicial, and political aspects of the Civil War and the process of emancipation and reunification. Though allegory predominates in Nast's illustration, vignettes depicting soldiers returning home and men and women celebrating victory frame the 
central symbolic image. One vignette portrays the battlefield dead, invoking a "victory dearly won." American women, the illustration implies, will enthrone the fallen president and the war dead in public and private shrines of memory. Nast's blending of the allegorical and the real, the symbolic feminine and the nonsymbolic feminine, underscores the centrality of female personifications to artistic and poetical depictions of the Civil War while indicating shifting conceptions of female political and social agency. ${ }^{62}$

\section{Liberty Enlightening the World}

"The Statue of Freedom" (1864), a poem by Mrs. P. R. Woodbury published in The Liberator, celebrates the addition of the eponymous personification atop the Capitol building. ${ }^{63}$ Designed by Thomas Crawford in 1855, the statue was installed on December 2, $1863 .{ }^{64}$ Philip Reid, a slave working at a foundry in Washington, DC, oversaw the casting of the bronze statue. ${ }^{65}$ An excerpt from the New York Tribune precedes the poem and ties Freedom, a female figure who combines characteristics of Columbia and Lady Liberty, to the course of the war and emancipation: "During more than two years of our struggle, while the national cause has seemed weak, she has patiently waited and watched below; now that victory crowns our advances, and the bond are being freed, she comes forward, her hand outstretched as if in guaranty of National Unity and Personal Freedom." During the Civil War, while American women "waited and watched" and came forward to serve the cause, figures like Freedom, Lady Liberty, and Columbia performed significant cultural and political work. When Edouard de Laboulaye, the president of France's Anti-Slavery Society, proposed a monument honoring the United States and Union victory in 1865 , he imagined a figure similar to the one atop the Capitol building. Ten years later, he and the sculptor Frédéric Auguste Bartholdi designed a powerful and monumental woman dressed in classical robes trampling a broken chain. ${ }^{66}$ La Liberté éclairant le monde, more commonly known as the Statue of Liberty, holds high her torch and, like the Statue of Freedom, illustrates the ongoing importance of the symbolic feminine to American identity. Lady Liberty's ancestry includes Columbia, her sisters, and the American women, both figurative and actual, who fought the Civil War and deserve recognition in the canon of Civil War literature.

\section{Notes}

1. S.J.A., "Not Dead," Harper's Weekly 5, no. 230 (May 25, 1861): 322.

2. Drew Gilpin Faust, Southern Stories: Slaveholders in Peace and War (Columbia: University of Missouri Press, 1992), 112.

3. A growing body of scholarship documents the wartime contributions and experiences of Northern and Southern women. For an expansive study of the war work of Northern women, see Nina Silber, Daughters of the Union: Northern Women Fight the Civil War (Cambridge, MA: Harvard University Press, 2005); for a seminal discussion of Southern women's roles, see Drew Gilpin Faust, Mothers of Invention: Women of the Slaveholding South in the American Civil War (Chapel Hill: University of North Carolina Press, 1996). Catherine Clinton and Nina Silber's col- 
lections Divided Houses: Gender and the Civil War (New York: Oxford University Press, 1992) and Battle Scars: Gender and Sexuality in the American Civil War (New York: Oxford University Press, 2006) include a number of essays detailing women's roles during the Civil War. For studies of nursing during the war, see Libra R. Hilde, Worth a Dozen Men: Women and Nursing in the Civil War South (Charlottesville: University of Virginia Press, 2012); Jane E. Schultz, Women at the Front: Hospital Workers in Civil War American (Chapel Hill: University of North Carolina Press, 2004). For information about women soldiers, see DeAnne Blanton and Lauren M. Cook, They Fought like Demons: Women Soldiers in the American Civil War (Baton Rouge: Louisiana State University Press, 2002).

4. For representative examples of Northern poems about nurses, see A. S. Hooker's ode to nurses, "Hospital Heroes," Frank Leslie's Illustrated Newspaper 16, no. 418 (October 3, 1863): 21; Sarah H. Powell's elegy for a fellow nurse who died of typhus fever, "In Memoriam," The Crutch 2, no. 55 (January 21, 1865): 1, Archives of Maryland Online, http://aomol.net; Charles W. Denison's elegy for a volunteer nurse, "In Memoriam," The Soldier's Friend 1, no. 4 (March, 1865): 1. For examples of Northern poems and articles about women's roles during the war, see "Knitting Socks" (1861), American Broadsides and Ephemera, Series 1, American Antiquarian Society no. 1023, http://infoweb.newsbank.com; James L. Roche, "The Woes of Columbia," The Liberator 32 , no. 6 (February 7, 1862): 24; Harriet M'Ewen Kimball, "Woman-1862," The Liberator 32, no. 46 (November 14, 1862): 184; “American Women," The Continental Monthly 6, no. 4 (October 1864): 416. For Southern examples, see Rosa Wild, "On Guard," The Southern Illustrated News 1, no. 22 (February 7, 1863): 3; Cornelia J. M. Jordan, "Flowers for a Sick Soldier," The Magnolia Weekly 2, no. 16 (January 16, 1864): 121; “The Women of Sparta," The Weekly Register (Lynchburg, VA) 1, no. 1 (January 2, 1864): 8; "The Brave at Home," University of North Carolina Archive, 172, Confederate Papers, Scrapbook Clippings.

5. Barbara Johnson, "Women and Allegory" in The Wake of Deconstruction (Cambridge, MA: Blackwell Publishers, 1994), 54.

6. de Man differentiates between symbol and allegory, arguing that symbols allow for identification. Paul de Man, "The Rhetoric of Temporality" in Blindness and Insight: Essays in the Rhetoric of Contemporary Criticism (Minneapolis: University of Minnesota Press, 1983), 187-228.

7. Mary P. Ryan, Women in Public: Between Banners and Ballots, 1825-1880 (Baltimore: Johns Hopkins University Press, 1990), 52. Elizabeth Young, Disarming the Nation: Women's Writing and the American Civil War (Chicago: University of Chicago Press, 1999), 49. Ryan does not discuss Civil War era women in public.

8. Anne Norton, Alternative Americas: A Reading of Antebellum Political Culture (Chicago: University of Chicago Press, 1986).

9. Shirley Samuels, Romances of the Republic: Women, the Family, and Violence in the Literature of the Early American Nation (New York: Oxford University Press, 1996), 13.

10. C. Dallett Hemphill, Siblings: Brothers and Sisters in American History (New York: Oxford University Press, 2011), 131.

11. Amy Murrell Taylor, The Divided Family in Civil War America (Chapel Hill: University of North Carolina Press, 2005), 2.

12. Drew Gilpin Faust, The Creation of Confederate Nationalism: Ideology and Identity in the Civil War South (Baton Rouge: Louisiana State University Press, 1988), 11-15, 84.

13. Patricia Vettel-Becker, "Sacagawea and Son: The Visual Construction of America's Maternal Feminine," American Studies 50: 1/2 (2009): 27-50.

14. Latin for "stood the mournful Mother weeping." See Julie Kristeva's "Stabat Mater," trans. Arthur Goldhammer, Poetics Today 6: 1/2 (1985): 133-52.

15. See E. McClung Fleming's discussion of the prevalence of personified nations and continents in art in "From Indian Princess to Greek Goddess: The American Image, 1783-1815," Winterthur Portfolio 3 (1967): 50. For a discussion of female allegories, see Marina Warner, Monuments and Maidens: The Allegory of the Female Form (Berkeley: University of California Press, 1985).

16. For a discussion of the racial politics of artistic portrayals of a Native American America, see Shirley Samuels, Romances of the Republic: Women, the Family, and Violence in the Literature of the Early American Nation (New York: Oxford University Press, 1996), 3-10.

17. Shirley Samuels, Romances of the Republic: Women, the Family, and Violence in the Literature of the Early American Nation (New York: Oxford University Press, 1996), 12. E. McClung Fleming, "The American Image as Indian Princess," Winterthur Portfolio 2 (1965): 65.

18. According to John Higham, "Americans spoke almost interchangeably" of the two figures (63), and this interchangeability is reflected in the pictorial and literary record. John Higham, "Indian Princess and Roman Goddess: The First Female Symbols of America," Proceedings of the American Antiquarian Society 100, no. 1 (1990): 79.

19. Joshua C. Taylor, with a contribution by John G. Cawelti, America as Art (Washington, DC: Smithsonian Institution Press, 1976), 7.

20. For a discussion of personifications of the goddess of Liberty, see Maurice Algulhon, Marianne into Battle: Republican Imagery and Symbolism in France, 1789-1880, trans. Janet 
Lloyd (Cambridge: Cambridge University Press, 1981); Martha Banta, Imaging American Women: Idea and Ideals in Cultural History (New York: Columbia University Press, 1987).

21. E. McClung Fleming argues that the early nineteenth century "saw both the Indian Princess and the Greek goddess replaced, in popular arts, by the masculine figures of Brother Jonathan and Uncle Sam." He also asserts that the advent of male personifications added "a missing flexibility, vitality, and robustness to the American image." "The American Image as Indian Princess," Winterthur Portfolio 2 (1965): 65-66.

22. For information on Civil War cartoons and the differences between Northern and Southern cartoons, see Kristen M. Smith, The Lines Are Drawn: Political Cartoons of the Civil War (Athens, GA: Hill Street Press, 1999).

23. John Higham identifies Columbia as the "most common personification of the Union" in humor magazines published during the war. John Higham, "Indian Princess and Roman Goddess: The First Female Symbols of America," Proceedings of the American Antiquarian Society 100, no. 1 (1990): 79.

24. Kristen M. Smith, The Lines Are Drawn: Political Cartoons of the Civil War (Athens, GA: Hill Street Press, 1999), xviii. 1865.

25. These statistics are based on my survey of both publications between the years 1861 and

26. Miss Columbia Calls Her Unruly School to Order (1860), in Lines of Contention: Political Cartoons of the Civil War, ed. J. G. Lewin and P. J. Huff (New York: HarperCollins, 2007), 12.

27. Soon to Be Out of a Job (1860), in Lines of Contention: Political Cartoons of the Civil War, ed. J. G. Lewin and P. J. Huff (New York: HarperCollins, 2007), 29.

28. For accounts of women's work related to sewing during the war, see Francis Butler Simkins and James Welch Patton, The Women of the Confederacy (Richmond, VA: Garrett and Massie, 1936), 23-26; Marilyn Mayer Culpepper, Trials and Triumphs: Women of the American Civil War (East Lansing: Michigan State University Press, 1991), 245-48.

29. Columbia Awake at Last, Harper's Weekly 5, no. 232 (June 8, 1861): 368. 1862): 40

30. James Ryder Randall, "My Maryland," The Southern Literary Messenger 36 (January 1,

31. Richard E. Mezo, "Randall, James Ryder,” American National Biography Online, http:// www.anb.org/articles/16/16-01342.html (2000). I found the poem in The Southern Literary Messenger, The Jacksonville Republican (May 23, 1861), and on two broadsides published during the war.

32. For information about Randall and his composition of the "My Maryland," see John Wilber Jenkins, "The Poems of James Ryder Randall," The South Atlantic Quarterly 7 (January to October, 1908): 242-47.

33. For a discussion of Lincoln's use of the familial metaphor, see Amy Murrell Taylor, The Divided Family in Civil War America (Chapel Hill: University of North Carolina Press, 2005), 1.

34. Oliver Wendell Holmes Sr., "Brother Jonathan's Lament for Sister Caroline," The Atlantic Monthly 7, no. 43 (May 1861): 613.

35. G.E.D., "Two Pictures of the South," The Liberator 31, no. 27 (July 5, 1861): 108.

36. William Cullen Bryant, "Our Country's Call," in Poems of American History, ed. Burton Egbert Stevenson (Boston: Houghton Mifflin, 1908), 410-11. Originally published in New York Ledger (November 2, 1861). William Cullen Bryant, "Not Yet," The Liberator 31, no. 34 (August 23, 1861): 136; The Smoky Hill and Republican Union [Junction City, Kansas] (September 12, 1861).

37. Howard Glyndon [Laura Redden Searing], "The Legend of Our Victories," in Idylls of Battle and Poems of the Rebellion (New York: Hurd and Houghton, 1864), 27-32.

38. Howard Glyndon [Laura Redden Searing], "Union Forever," in Idylls of Battle and Poems of the Rebellion (New York: Hurd and Houghton, 1864), 48-52. 1862): 1 .

39. Charles A. Barry, "Columbia's Invocation," The New South 1, no. 6 (September 13,

40. See Jane E. Schultz's "The Inhospitable Hospital: Gender and Professionalism in Civil War Medicine," Signs 17, no. 2 (1992): 363. 1863): 4 .

41. Abduction of the Yankee Goddess of Liberty, Southern Punch 1, no. 14 (November 14,

42. William Shakespeare, Macbeth 5.1.36.

43. Check-Mate! Harper's Weekly 9, no. 440 (June 3, 1865): 337.

44. Peter S. Duval, In Defence of the Union and the Constitution (Philadephia: P. S. Duval and Son, 1861), Library of Congress Prints and Photographs Online Catalog, http://hdl.loc.gov/loc. pnp/pga.03676.

45. Ehrgott, Forbriger, \& Co., lithographer, The Union Defenders Certificate (1863), Library of Congress Prints and Photographs Online Catalog, http://hdl.loc.gov/loc.pnp/cph.3b37096.

46. Columbia to Lincoln, Harper's Weekly 7, no. 314 (January 3, 1863): 16.

47. J. E. Baker, Columbia Demands Her Children, (Boston, 1864), Library of Congress Prints and Photographs Online Catalog, http://hdl.loc.gov/loc.pnp/ppmsca.15768. 
48. For a discussion of the wartime work of women abolitionists, see Wendy Hamand Venet's Neither Ballots nor Bullets: Women Abolitionists and the Civil War (Charlottesville: University Press of Virginia, 1991), 2.

49. For a discussion of the participation of free African American women in the antislavery movement, see Shirley J. Yee's Black Women Abolitionists: A Study in Activism, 1828-1860 (Knoxville: University of Tennessee Press, 1992).

50. William Lloyd Garrison, "Our National Visitation," The Liberator 32, no. 28 (July 11, 1862): 112.

51. "National Ode: Suggested by the President's Proclamation of January 1, 1863," The Continental Monthly 3, no. 5 (May 1863): 554.

52. "Maryland in Fetters" (1861), Confederate Broadside Poetry Collection, WakeSpace Digital Archive, http://hdl.handle.net/10339/164.

53. "November 8, 1864." Harper's Weekly 8, no. 413 (November 26, 1864): 754.

54. Charles Kimmel, The End of the Rebellion in the United States, 1865 (New York: Kimmel and Foster, 1866), Library of Congress Prints and Photographs Online Collection, http://hdl.loc. gov/loc.pnp/cph.3a15123.

55. Drew Gilpin Faust, This Republic of Suffering: Death and the American Civil War (New York: Knopf, 2008), 149. 1862): 1 .

56. "The Soldier's Grave," Freedom's Champion [Atchinson City, Kansas] (September 20,

57. Thomas Nast, Honor the Brave, Harper's Weekly 7, no. 356 (October 24, 1863): 680-81.

58. Thomas Nast, Compromise with the South, Harper's Weekly 8, no. 401 (September 3, 1864): 572 .

59. Abraham Lincoln's Coffin. Harper's Weekly 9, no. 435 (April 29, 1865): 267-68.

60. “A Dirge-April 15, 1865," The Liberator 35, no. 9 (May 12, 1865): 76.

61. Thomas Nast, Our Arms Victorious, Harper's Weekly 9, no. 443 (June 24, 1865): 392-93.

62. For further examples of the close alignment of the symbolic feminine and Union victory, see Thomas Nast, The Blessing of Victory, Harper's Weekly 3, no. 404 (September 4, 1864): 616; Bayard Taylor, "Comments," The Liberator 34, no. 29 (July 15, 1864): 116; "America Is Free," The Crutch 2, no. 71 (May 13, 1865): 1; W. J. Linton, "Columbia Victrix," The Liberator 35, no. 24 (June 16, 1865): 96; Mrs. A. D. T. Whitney, "Peace," The Liberator 35, no. 33 (August 18, 1865): 132.

63. Mrs. P. R. Woodbury, "The Statue of Freedom," The Liberator 34, no. 3 (January 15, 1864): 12.

64. "The Statue of Freedom," Architect of the Capitol, http://www.aoc.gov/cc/art.

65. Eugene Walton, "Philip Reed: Slave Caster of Freedom," The Examiner [Washington] (March 1, 2005), republished in Chicken Bones, http://www.nathanielturner.com.

66. Statue of Liberty. National Park Service, 2014. http://www.nps.gov/stli/historyculture/ people.htm. 
